\title{
An Analysis of Secondary School Students' Anxiety Levels According to Parameters of Gender, Grade Level, Socioeconomic Level and Reading Frequency
}

\author{
Yusuf GENÇER ${ }^{1} \&$ Sercan DEMIRGÜNEŞ ${ }^{1}$ \\ ${ }^{1}$ Department of Turkish Education, Faculty of Education, Nigde Ömer Halisdemir Universty, Nigde, Turkey \\ Correspondence: Sercan DEMIRGÜNEŞ, Department of Turkish Education, Faculty of Education, Nigde Ömer \\ Halisdemir Universty, Nigde, Turkey.
}

Received: May 1, 2019

doi:10.5539/ies.v12n9p91
Accepted: June 4, 2019 Online Published: August 29, 2019

URL: https://doi.org/10.5539/ies.v12n9p91

\begin{abstract}
The aim of this study is to examine the reading anxiety levels of secondary school students according to parameters of gender, grade level, socioeconomic level and reading frequency. The total number of participants of the study is 598 who are students in a secondary school from different grade levels. In this study, reading anxiety scale and personal information form is used. The collected data is analyzed by using independent $t$-test, one-way analysis of variance and Pearson Product-Moment Correlation Coefficient. Just as the first result of the study, it has been found that the reading anxiety levels of secondary school students are low. No significant difference has been found between the levels of students' reading anxiety and the levels of gender and grade. However, the students' reading anxiety levels has differed significantly in favor of those with high socioeconomic level. According to the latest finding obtained from the study, the reading anxiety levels of the students has differed significantly in favor of those who have low reading frequency. Therefore, students reading less have more reading anxiety. These results obtained from the study are discussed as stated to the literature.
\end{abstract}

Keywords: reading, anxiety, reading anxiety, reading frequency

\section{Introduction}

Reading, both socially and emotionally, is one of the important skills that provide the development of the individual. It is necessary for the individual to have a good reading skill to be successful and happy, and to develop his personality throughout his life (Dökmen, 1994). It has been seen that reading skill, which is among one of the skills related to comprehension, is important in order to regulate the lives of individuals, to socialize and to improve their quality of life.

In the literature, it is possible to find many definitions concerning the concept of reading. Göğüş $(1978$, p. 60) describes reading as "to recognize the letters and words of a text and to grasp their meaning", while Demirel (1999, p. 59) defines it as "the activity of getting meaning from written symbols with the help of cognitive behaviors and psychomotor skills". Çetinkaya (2010) defines reading as the process of signifying and interpreting the signs and symbols in the brain perceived by auditory and visual organs. Therefore, with these definitions in mind, reading is a complete, fluent and consequential action where understanding takes place as a result. There are many factors, such as cognitive, affective, psychomotor and environmental, affecting the reading process. The affective factor is frequently investigated in the studies related to reading along with its effects on the reading process. Affective factors in the reading process include concepts such as attitude, motivation and anxiety. It has been shown that reading attitude and motivation affect reading, reading comprehension and academic achievement. Anxiety is a negative emotion that an individual may face in academic fields and in daily life.

Anxiety is a feeling of helplessness and fear that can occur in the earliest stages of life, damaging attention skills, negatively affecting learning, and threatening self-esteem of the individual (Jalongo \& Hirsh, 2010). At the same time, extreme and arbitrary fear (Bandura, 1997) is a feeling of anxiety and helplessness in the face of potential harmful events (Seven, 2008). When these definitions are considered, obviously the effect of anxiety on life is not to be underestimated.

Jalongo and Hirsh (2010) stated that anxiety, fear, and phobias constitute a major obstacle to one's reading skill. Zin and Rafik-Galea (2010) reported that the level of anxiety significantly affects the reading performance of 
individuals.

According to the literature, studies related to anxiety have focused on the exam anxiety (Yıldırım, 2000; Başpınar-Can, Dereboy, \& Eskin, 2012; Güler \& Çakır, 2013), and also on subjects related to anxiety in foreign language learning (Yıldırım, 2007; Aydın \& Zengin, 2008; Tuncel, 2014).

When the anxiety studies related to the four basic language skills are examined, the studies focus mainly on speech anxiety (Sevim, 2012; Yaman \& Suroğlu-Sofu, 2013; Sevim \& Gedik, 2014; Demir \& Melanlığlu, 2014; Lüle-Mert, 2015) and writing anxiety (Uçgun, 2011; Karakaya \& Ülper, 2011; İşeri \& Ünal, 2012; Tiryaki, 2012). However, the reading anxiety studies on the acquisition of native language are limited. Therefore, considering the lack of reading anxiety studies on native language acquisition, it is important to reveal the students' reading anxiety in all levels of education and to take measures to reduce reading anxiety based on this concept, and especially considering the scarcity of studies in the related literature, it is important to reveal the relationship between reading anxiety and reading frequency.

The aim of this study is to evaluate the reading anxiety status of secondary school students according to parameters of gender, grade level, socioeconomic level and reading frequency. With this purpose in mind, the problem statement of the study can be determined as "What is the level of reading anxiety of secondary school students?". According to this problem statement, the following sub problems can be listed:

1) Do the reading anxiety levels of secondary school students differ by gender?

2) Do the reading anxiety levels of secondary school students vary according to grade levels?

3) Do the reading anxiety levels of secondary school students differ according to socioeconomic level?

4) Is there a relationship between the reading anxiety levels and the reading frequency of secondary school students?

\section{Method}

This study is structured using the scanning technique from quantitative research methods as it aims to present an existing situation as it is. Descriptive and comparative statistical techniques are used in the analysis. Karasar (2005) defines scanning technique as a method of collection of data by studying on current documentaries. Also, there are two kinds of scanning technique, one of them is general scanning and another one is content analysis. In this study, data is structured by general scanning.

\section{Working Group}

The scale used in this study has been applied to 598 students studying in the $5^{\text {th }}, 6^{\text {th }}, 7^{\text {th }}$ and $8^{\text {th }}$ grades of secondary schools and the schools are representative of LOWER socioeconomic level, MIDDLE socioeconomic level and UPPER socioeconomic level in Niğde province. Table 1 shows the distribution of the study group by gender, socioeconomic level and grade level.

Table 1. Frequency and percentages of demographic characteristics of the working group

\begin{tabular}{llccc}
\hline & & $\boldsymbol{f}$ & $\mathbf{\%}$ & $\mathbf{\%}_{\mathbf{y i g}}$ \\
\hline \multirow{3}{*}{ Gender } & FEMALE & 285 & 47.7 & 47.7 \\
& MALE & 313 & 52.3 & 100.0 \\
Socioeconomic Level & LOWER & 191 & 31.9 & 31.9 \\
& MIDDLE & 221 & 37.0 & 68.9 \\
& UPPER & 186 & 31.1 & 100.0 \\
Grade & 5th grade & 152 & 25.4 & 25.4 \\
& 6th grade & 151 & 25.3 & 50.7 \\
Total & 7th grade & 134 & 22.4 & 73.1 \\
& 8th grade & 161 & 26.9 & 100.0 \\
& & 598 & 100.0 & 100.0 \\
\hline
\end{tabular}

As shown in Table 1, out of 598 students, 285 (47.7\%) are female and 313 (52.3\%) are male. In the socioeconomic level, 191 (31.9\%) students are from the lower, 221 (37.0\%) are from the middle and $186(31.1 \%)$ are from the upper socioeconomic level. Of the secondary school students, $152(25.4 \%)$ are in the $5^{\text {th }}$ grade, $151(25.3 \%)$ are in the $6^{\text {th }}$ grade, $134(22.4 \%)$ are in the $7^{\text {th }}$ grade and $161(26.9 \%)$ are in the $8^{\text {th }}$ grade. 


\section{Data Collection Tools}

\subsection{Reading Anxiety Scale}

In this study, the scale developed by Çeliktürk and Yamaç (2015), "Reading Anxiety Scale for Primary and Secondary School Students", has been used as the data collection tool. This scale is a Likert type scale consisting of 29 items. A maximum of 145 points and a minimum of 29 points can be obtained from the scale. After getting the permission of the authors, the scale was applied. The scale has a single factor structure and the total variance is 55.87. In addition to this, the internal consistency coefficient for the reliability of the scale is 0.95 (Çeliktürk \& Yamaç, 2015).

\subsection{Personal Information Form}

The Personal Information Form developed by the researcher was used to collect data related to the independent variables of the scale. In the form, there are four questions asking the gender of the students, grade levels, their frequency of reading and the name of their schools, in order to determine their socioeconomic levels.

\section{Data Analysis}

In this study, the evaluations are made based on 598 scales filled by the participants. In order to calculate the scores, the following ratio is used: "Never" 1, "Rarely" 2, "Occasionally" 3, "Most of the time" 4 and "Always" 5 points. As a result of the analysis, the findings obtained for the problem statement range is as follows; "Never" 1.00-1.79, "Rarely" 1.80-2.59, "Occasionally" 2.60-3.39, "Most of the time" 3.40-4.19 and "Always" 4.20-5.00.

Findings related to sub problems are analyzed using independent t-test, one-way ANOVA and Pearson Product Moment Correlation Coefficient.

\section{Results}

\subsection{Findings Related to the Problem Clause}

The mean score taken from the scale is found to be 1.81 for the following problem statement question; "what is the reading anxiety level of secondary school students?" The average is in the range of "Rarely".

\subsection{Findings Related to Subproblem Clauses}

Table 2. The results of unrelated group t-test for the differentiation status of primary school students' reading anxiety levels according to gender variable

\begin{tabular}{ccccccc}
\hline & \multirow{2}{*}{$\overline{\mathrm{n}}$} & $\overline{\boldsymbol{X}}$ & $\mathrm{ss}$ & \multicolumn{3}{c}{$\mathrm{t}$ Test } \\
\cline { 5 - 7 } & & & & $\mathrm{t}$ & $\mathrm{sd}$ & $\mathrm{p}$ \\
\hline FEMALE & 285 & 1.78 & .82 & -.917 & 596 & .360 \\
MALE & 313 & 1.84 & .88 & & & \\
\hline
\end{tabular}

According to Table 2, reading anxiety levels of primary school students $(\mathrm{n}=598)$ has not shown a significant difference at .05 level according to gender variable. The arithmetic mean of female students $(n=285)$ is 1.78 , the standard deviation is .82 and the arithmetic mean of male students $(n=313)$ is 1.84 , and the standard deviation is $.88(88)$.

Table 3. ANOVA test results for differentiation status of primary school students' reading anxiety levels according to socioeconomic level variable

\begin{tabular}{lcccccc}
\hline & $\mathrm{n}$ & $\overline{\boldsymbol{X}}$ & $\mathrm{Ss}$ & $\mathrm{F}$ & $\mathrm{p}$ & Difference \\
\hline 1) LOWER & 191 & 2.43 & .83 & & & \\
2) MIDDLE & 221 & 1.67 & .72 & & & $1>2$ \\
3) UPPER & 186 & 1.35 & .60 & 113.815 & .000 & $1>3$ \\
Total & 598 & 1.81 & .85 & & & $2>3$ \\
\hline
\end{tabular}

When Table 3 is examined, it is seen that reading anxiety levels of primary school students $(n=598)$ show a significant difference at .05 level according to socioeconomic level variable. Of the students from the lower socioeconomic level $(\mathrm{n}=191)$, the standard deviation is .83 , and the arithmetic mean is 2.43 . Of the students from the middle socioeconomic level $(\mathrm{n}=221)$, the arithmetic mean is 1.67 , the standard deviation is .72 . Of the upper 
socioeconomic level $(\mathrm{n}=186)$, the arithmetic mean is 1.35 , the standard deviation is .60 . According to this, it was determined that the students' reading anxiety level at lower socioeconomic levels was higher than the reading anxiety levels of middle and upper socioeconomic level students, and the reading anxiety levels of students at the upper socioeconomic level were higher than the students in the upper socioeconomic level. With these results at hand, it is possible to conclude that the socioeconomic level variable is a factor in reading anxiety. As the socioeconomic level decreases, the level of reading anxiety increases.

Table 4. ANOVA test results for differentiation status of primary school students' reading anxiety levels by grade level variable

\begin{tabular}{lcccccr}
\hline & $\mathrm{n}$ & $\overline{\boldsymbol{X}}$ & $\mathrm{Ss}$ & $\mathrm{F}$ & $\mathrm{p}$ & Difference \\
\hline 5th GRADE & 152 & 1.77 & .80 & & & \\
6th GRADE & 151 & 1.85 & .88 & & & \\
7th GRADE & 134 & 1.82 & .84 & .243 & .866 & \\
8th GRADE & 161 & 1.82 & .87 & & & \\
Total & 598 & 1.81 & .85 & & & \\
\hline
\end{tabular}

When Table 4 is analyzed, reading anxiety levels of primary school students $(n=598)$ has not shown a significant difference at .05 level according to grade level variable. The arithmetic average of the fifth-grade students $(\mathrm{n}=$ $152)$ is 1.77 , the standard deviation is .80 . The arithmetic average of the sixth-grade students $(n=151)$ is 1.85 , the standard deviation is .88 . The arithmetic average of the seventh-grade students $(\mathrm{n}=134)$ is 1.82 , standard deviation is .84 . The arithmetic average of eighth-grade students $(n=161)$ is 1.82 , the standard deviation is 87 .

Table 5. Results of Pearson product moment correlation coefficient concerning the relationship between the reading anxiety levels of primary school students and the frequency of reading

\begin{tabular}{lcc}
\hline & Reading anxiety & Reading frequency \\
\hline Reading anxiety & 1 & -.33 \\
Reading frequency & -.33 & 1 \\
\hline
\end{tabular}

$* \mathrm{p}<.01$.

According to Table 5, a significant relationship has been found between primary school students' $(\mathrm{n}=598)$ reading anxiety levels and the frequency of reading books. According to Büyüköztürk (2014, p. 32), although the correlation coefficient (r) is not fully coherent on the interpretation of its magnitude, the correlation coefficient, being the absolute value, is considered high if it is between 0.70-1.00; moderate if it is between 0.70-0.30; and low if it is between 0.30-0.00. According to this information, it is seen that there is a moderate $(r=.33, p<.01)$, negative and significant relationship between the reading anxiety levels of primary school students and the frequency of reading books. Besides, it has been found that primary school students' reading anxiety levels decreased as the frequency of reading increased, and the reading anxiety levels increased as the frequency of reading decreased.

\section{Conclusion and Discussion}

By analyzing the data obtained in this study, it can be seen that the reading anxiety of secondary school students is lower than average. Looking at the results, it is understood that secondary school students are devoted to reading; Turkish courses are successful in encouraging reading and lower reading anxiety affects the reading performance in a positive way.

It was found that there is no significant difference in reading anxiety of secondary school students in terms of gender. The results of Yildiz and Ceyhan's (2016) studies on $4^{\text {th }}$ grade students also support this finding.

It has been observed that there is no significant difference between the level of reading anxiety and the grade level of secondary school students. This means that the reading anxiety levels of secondary school students are approximately the same at each grade level.

A significant difference has been found between reading anxiety levels and socioeconomic status of secondary school students. As the socioeconomic level decreases, the level of reading anxiety increases and also the level of reading anxiety decreases as the socioeconomic level increases. Within the framework of these findings, it can be 
concluded that the socioeconomic level variable is an important factor in reading anxiety.

A moderate negative relationship has been found between the reading anxiety levels of secondary school students and the frequency of reading books. Considering these findings, it has been concluded that the reading anxiety levels decreases as the reading frequency increases and the reading anxiety levels increases as the reading frequency decreases for the secondary school students.

Generally speaking, there is no significant difference between secondary school students' reading anxiety levels, gender and grade level, but a significant difference has been found between the socioeconomic level and the anxiety level. At the same time, it has been found that there is a moderate relationship between the reading anxiety levels and the frequency of reading books of secondary school students.

Considering all these results of the study, it is recommended that teachers of Turkish could practice activities that will encourage students to read more books in order to reduce their reading anxiety levels since no improvement on the socioeconomic level of the students can be achieved by the teachers.

\section{References}

Aydın, S., \& Zengin, B. (2008). Yabancı Dil Öğreniminde Kaygı: Bir Literatür Özeti. Journal of Language and Linguistic Studies, 4(1), 81-94.

Bandura, A. (1997). Self-efficacy: The exercise of control. New York: W. H. Freeman.

Başpınar-Can, P., Dereboy, Ç., \& Eskin, M. (2012). Yüksek Riskli Sınav Kaygısının Azaltılmasında Sistematik Duyarsızlaştırma ile Bilişsel Yeniden Yapılandırmanın Etkililiğinin Karşılaştırılması. Türk Psikiyatri Dergisi, 23(1), 9-17.

Büyüköztürk, Ş. (2014). Sosyal Bilimler İçin Veri Analizi El Kitabı. Ankara: Pegem A Yayıncılık.

Çeliktürk, Z., \& Yamaç, A. (2015). İlkokul ve Ortaokul Öğrencileri İçin Okuma Kaygısı Ölçeğinin Geliştirilmesi: Geçerlik ve Güvenirlik Çalışması. İlköğretim Online, 14(1), 97-107. https://doi.org/10.17051/io.2016.42123

Çetinkaya, G. (2010). Türkçe metinlerin okunabilirlik düzeylerinin tanımlanması ve sinıflandırılması (Unpublished doctoral thesis). Ankara University Social Sciences Institute, Ankara.

Demir, T., \& Melanlıoğlu, D. (2014). Ortaokul Öğrencileri İçin Konuşma Kaygısı Ölçeği: Geçerlik ve Güvenirlik Çalı̧̧ması. Ankara Üniversitesi Eğitim Bilimleri Fakültesi Dergisi, 47(1), 103-124. https://doi.org/10.1501/Egifak_0000001319

Demirel, Ö. (1999). İlköğretim Okullarında Türkçe Öğretimi. İstanbul: MEB Yayınları.

Dökmen, Ü. (1994). Okuma Becerisi, Illgisi ve Alışkanlı̆̆ Üzerine Psiko-sosyal Bir Araştırma. Ankara: Milli Eğitim Basımevi.

Göğüş, B. (1978). Orta Dereceli Okullarımızda Türkçe ve Yazın Eğitimi. Ankara: Gül Yayınevi.

Güler, D., \& Çakır, G. (2013). Lise Son Sınıf Öğrencilerinin Sınav Kaygısını Yordayan Değişkenlerin İncelenmesi. Türk Psikolojik Danışma ve Rehberlik Dergisi, 4(39), 82-94.

İşeri, K., \& Ünal, E. (2012). Türkçe Öğretmen Adaylarının Yazma Kaygı Durumlarının Çeşitli Değişkenler Açısından İncelenmesi. Mersin Üniversitesi Eğitim Fakültesi Dergisi, 8(2), 67-76.

Jalongo, M. R. \& Hirsh, R. A. (2010). Understanding Reading Anxiety: New Insights from Neuroscience. Early Childhood Education Journal, 37, 431-435. https://doi.org/10.1007/s10643-010-0381-5

Karakaya, İ., \& Ülper, H. (2011). Yazma Kaygısı Ölçeğinin Geliştirilmesi ve Yazma Kaygısının Çeşitli Değişkenlere Göre İncelenmesi. Kuram ve Uygulamada Eğitim Bilimleri, 11(2), 691-707.

Karasar, N. (2005). Bilimsel araştırma yöntemi (15. baskı). Ankara: Nobel Yayın Dağıtım.

Lüle-Mert, E. (2015). Türkçe öğretmeni adaylarının konuşma kaygılarına ilişkin bir inceleme. Uluslararası Sosyal Araştırmalar Dergisi, 37(8), 784-789. https://doi.org/10.17719/jisr.20153710644

Seven, S. (2008). Çocuk Ruh Sağll̆̆g. Ankara: PEGEMA Yayınları.

Sevim, O. (2012). Öğretmen adaylarına yönelik konuşma kaygısı ölçeği: bir geçerlik ve güvenirlik çalışması. Turkish Studies, 7(2), 927-937.

Sevim, O., \& Gedik, M. (2014). Ortaöğretim öğrencilerinin konuşma kaygılarının çeşitli değişskenler açısından incelenmesi. Atatürk Üniversitesi Türkiyat Araştırmalarl Enstitüsü Dergisi, 52, 379-393. https://doi.org/10.14222/Turkiyat1236 
Tiryaki, E. N. (2012). Üniversite öğrencilerinin yazma kaygısının çeşitli değişkenleraçısından belirlenmesi. Dil ve Edebiyat Eğitimi Dergisi, 1(1), 14-21.

Tunçel, H. (2014). Yabancı dil öğretimine yönelik kaygı çalışmalarına genel bir bakış. Route Educational and Social Science Journal, 1(2), 126-151. https://doi.org/10.17121/ressjournal.67

Uçgun, D. (2011). The Study in the Writing Anxiety Levels of Primary School 6, 7 and 8th Year Students in Terms of Several Variables. Educational Research and Reviews, 6(7), 542-547.

Yaman, H., \& Suroğlu-Sofu, M. (2013). Öğretmen adaylarına yönelik konuşma kaygısı ölçeğinin geliştirilmesi, TSA dergisi, 17(3), 41-50.

Yıldırım, İ. (2000). Akademik başarının yordayıcısı olarak yalnızlık, sınav kaygısı ve sosyal destek. Hacettepe Üniversitesi Eğitim Fakültesi Dergisi, 18, 167-176.

Yıldırım, S. (2007). Yabancı dil kaygısı: dinleme ve konuşma. Dokuz Eylül Üniversitesi Sosyal Bilimler Enstitüsü Dergisi, 9(3), 178-206.

Yıldız, M., \& Ceyhan, S. (2016). İlkokul 4. Sınıf Öğrencilerinin Okuma ve Yazma Kaygılarının Çeşitli Değişkenler Açısından İncelenmesi. Turkish Studies, 11(2), 1301-1316. https://doi.org/10.7827/TurkishStudies.9370

Zin, M. Z., \& Rafik-Galea, S. (2010). Anxiety and academic reading performance among Malay ESL learners. Journal of Pan-Pacific Association of Applied Linguistics, 14(2), 41-58.

\section{Copyrights}

Copyright for this article is retained by the author(s), with first publication rights granted to the journal.

This is an open-access article distributed under the terms and conditions of the Creative Commons Attribution license (http://creativecommons.org/licenses/by/4.0/). 